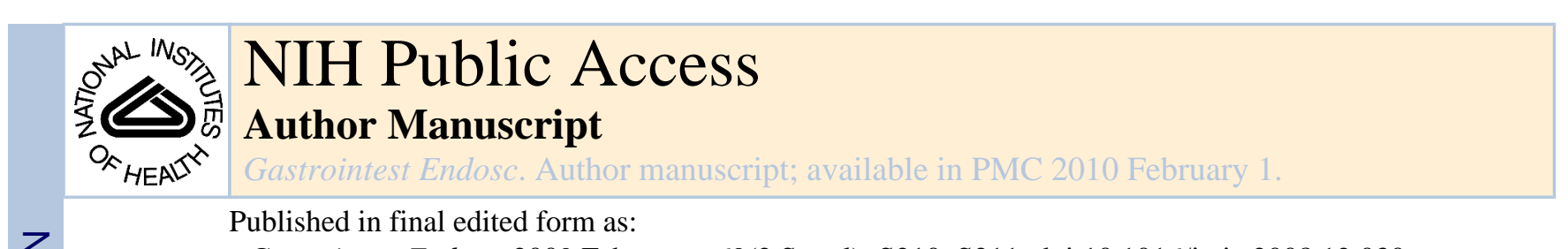

Published in final edited form as:

Gastrointest Endosc. 2009 February ; 69(2 Suppl): S210-S211. doi:10.1016/j.gie.2008.12.030.

\title{
EUS and NOTES
}

\author{
Amitabh Chak, MD \\ Cleveland, Ohio, USA
}

Natural orifice translumenal endoscopic surgery (NOTES), by definition, begins with an incision through the wall of the gastrointestinal tract. ${ }^{1,2}$ The anterior gastric wall has been the preferred port for NOTES peritoneal access in the porcine model as well as humans. ${ }^{1,2}$ The incision is made from within the lumen without the ability to image adjacent organs or blood vessels. Clinical experience with percutaneous endoscopic gastrostomy (PEG) and transgastric endoscopic pancreatic pseudocyst drainage procedures indicates that a blind trans-gastric incision or puncture can be performed with relatively low risk. However, just as the EUS guided approach is proposed (although not proven) to increase safety of transgastric pseudocyst drainage over the blind approach, ${ }^{3-6}$ EUS imaging could avoid the small but finite risk of inadvertent injury of adjacent organs and vessels that will inevitably be associated with a strictly endoscopic trans-gastric NOTES incision.

Furthermore, most pilot NOTES applications have restricted themselves to the anterior gastric port because the anterior gastric wall is easy to identify by abdominal palpation. ${ }^{1,2}$ The flexible endoscope is also in a relatively neutral position when approaching the anterior gastric wall. However, laparoscopic surgeons have learned the advantages of varying port location on the abdominal wall for specific procedures. Similarly it will be necessary to understand the nuance of trans-gastric (or trans-rectal or trans-vaginal) port localization as NOTES develops. EUS imaging should provide NOTES endoscopists the ability to perform translumenal incisions at sites most likely to provide optimal exposure of intra-abdominal organs they wish to approach for surgical purposes.

Novel applications of EUS for NOTES procedures have been proposed in the porcine model, including tissue apposition, gastrojejunostomy, lymph node dissection, posterior gastropexy, and even cardiac catheterization. ${ }^{7-11}$ We have systematically investigated EUS imaging for the most basic part of NOTES - the initial incision - using a prototype forward viewing interventional echoendoscope (GIF-UCT160J-AL5, Olympus Medical Systems Corp, Tokyo, Japan) in the porcine model. ${ }^{12}$ NOTES incisions were made in the rectum, posterior gastric wall, and gastric antrum at 16 locations defined as safe (no vessel or organ adjacent to the gastrointestinal wall) and 16 locations defined as unsafe by EUS. Incisions made in locations defined as safe were generally safe except for 3 rectal incisions, which resulted in small bowel injury. All "unsafe" incisions resulted in major injuries such as gallbladder perforation, liver laceration, arterial bleeding, and death. This pilot study suggests that EUS will play an integral role in avoiding injury to viscera or blood vessels when performing NOTES incisions in locations other than the anterior gastric wall.

\author{
DISCLOSURE \\ University Hospitals of Cleveland, Cleveland, Ohio, USA. \\ This article is from a meeting and has not undergone the GIE peer review process.
}

Publisher's Disclaimer: This is a PDF file of an unedited manuscript that has been accepted for publication. As a service to our customers we are providing this early version of the manuscript. The manuscript will undergo copyediting, typesetting, and review of the resulting proof before it is published in its final citable form. Please note that during the production process errors may be discovered which could affect the content, and all legal disclaimers that apply to the journal pertain. 
Small bowel injury was difficult to avoid during EUS-guided NOTES incisions because of air interference. Similarly, EUS has a limited ability to image t-tags introduced through the gastric wall. ${ }^{11}$ Standard endoscopic accessories are not designed to be songraphically visible. In general, EUS also has a steep learning curve. Improved technology will undoubtedly allow endoscopists to overcome some of these challenges as the NOTES movement expands. Future research will define whether EUS will lead to improved NOTES access and safer procedures as clinical applications of NOTES develop.

\section{References}

1. ASGE; SAGES. ASGE/SAGES Working Group on Natural Orifice Translumenal Endoscopic Surgery White Paper October 2005. Gastrointest Endosc 2006 Feb;63(2):199-203. [PubMed: 16427920]

2. Rattner D, Kalloo A. ASGE/SAGES Working Group. ASGE/SAGES Working Group on Natural Orifice Translumenal Endoscopic Surgery. October 2005. Surg Endosc 2006 Feb;20(2):329-33. [PubMed: 16402290]No abstract available

3. Sriram PV, Kaffes AJ, Rao GV, Reddy DN. Endoscopic ultrasound-guided drainage of pancreatic pseudocysts complicated by portal hypertension or by intervening vessels. Endoscopy 2005 Mar;37 (3):231-5. [PubMed: 15731938]

4. Giovannini M, Bernardini D, Seitz JF. Cystogastrotomy entirely performed under endosonography guidance for pancreatic pseudocyst: results in six patients. Gastrointest Endosc 1998 Aug;48(2):2003. [PubMed: 9717789]

5. Norton ID, Clain JE, Wiersema MJ, DiMagno EP, Petersen BT, Gostout CJ. Utility of endoscopic ultrasonography in endoscopic drainage of pancreatic pseudocysts in selected patients. Mayo Clin Proc 2001 Aug;76(8):794-8. [PubMed: 11499818]

6. Kahaleh M, Shami VM, Conaway MR, Tokar J, Rockoff T, De La Rue SA, de Lange E, Bassignani M, Gay S, Adams RB, Yeaton P. Endoscopic ultrasound drainage of pancreatic pseudocyst: a prospective comparison with conventional endoscopic drainage. Endoscopy 2006 Apr;38(4):355-9. [PubMed: 16680634]

7. Fritscher-Ravens A, Swain P. Future therapeutic indications for endoscopic ultrasound. Gastrointest Endosc Clin N Am 2005 Jan;15(1):189-208. xi. [PubMed: 15555961]Review

8. Fritscher-Ravens A, Mosse CA, Mukherjee D, Mills T, Park PO, Swain CP. Transluminal endosurgery: single lumen access anastomotic device for flexible endoscopy. Gastrointest Endosc 2003 Oct;58(4): 585-91. [PubMed: 14520300]Review

9. Fritscher-Ravens A, Mosse CA, Mills TN, Mukherjee D, Park PO, Swain P. A through-the-scope device for suturing and tissue approximation under EUS control. Gastrointest Endosc 2002 Nov;56 (5):737-42. [PubMed: 12397289]

10. Fritscher-Ravens A, Mosse CA, Ikeda K, Swain P. Endoscopic transgastric lymphadenectomy by using EUS for selection and guidance. Gastrointest Endosc 2006 Feb;63(2):302-6. [PubMed: 16427939]

11. Fritscher-Ravens A, Mosse CA, Mukherjee D, Yazaki E, Park PO, Mills T, Swain P. Transgastric gastropexy and hiatal hernia repair for GERD under EUS control: a porcine model. Gastrointest Endosc 2004 Jan;59(1):89-95. [PubMed: 14722559]

12. Elmunzer BJ, Schomisch SJ, Trunzo JA. EUS in localizing safe alternate access sites for natural orifice transluminal endoscopic surgery: preliminary experience in a porcine model. Gastrointest Endosc. To be published 